quantity of mercury vapour is present. It is not possible to mix a number of gases and vapours in one tube as each gas requires a definite voltage to stimulate it. It is not possible, for example, to harness a mixture of mercury and sodium vapour and neon gas in the same tube and so combine them to obtain a suitable radiation.

The fire-fly restricts its radiation to the visible spectrum only, whilst in the ordinary lamp a large proportion is emitted in the infra-red. The former is consequently an extremely efficient light source. If all the energy supplied to a discharge tube were emitted at a wave-length of 5,550 A., corresponding to the peak of the luminosity curve of the eye, the luminous efficiency would be about 670 lumens per watt. Compare this with the 12 lumens per watt of a 100 watt incandescent lamp. In practice it is now possible to make 100 watt sodium lamps with an efficiency of 70 lumens per watt. If the internal losses in the tube werenegligible, theory shows that the efficiency would be 360 lumens per watt. Pirani has obtained this efficiency in the laboratory but it is impossible, as yet at least, to obtain it in a commercial lamp.
The development of gaseous lamps has been taking place rapidly during the last year. By placing neon and mercury tubes in parabolic reflectors, very efficient lamps suitable for flood-lighting are obtained. A 400 watt lamp is being developed at Wembley which seems very suitable for lighting streets and important thoroughfares. The street outside the Wembley Laboratories was shown illuminated in this way with very satisfactory results. Some people might find difficulty in distinguishing a ld. stamp from a $1 \frac{1}{2} d$. stamp by the light from these lamps. Sodium lamps were developed first by Pirani in Berlin. There is a section of road admirably lighted by these lamps in Holland and another in Zurich. A similar lamp developed at Wembley is being tried for lighting stretches of arterial and country roads where the lack of good colour discrimination is of little importance.

Many avenues of research in connexion with gaseous lamps are still unexplored. It seems certain that their colour will soon be improved and that their efficiency will be very appreciably increased.

\title{
Industrial Research and National Problems
}

$\mathrm{S}^{\mathrm{IR}}$ FRANK SMITH, secretary of the Department of Scientific and Industrial Research, delivered the Norman Lockyer lecture of the British Science Guild on November 22, taking as his subject "Industrial Research and the Nation's Balance Sheet". Sir Arnold Wilson was in the chair.

Sir Frank Smith urged that the active prosecution of industrial research is essential for impruving Great Britain's national balance sheet, which in the past ten months has shown an apparent adverse balance of some $£ 263,749,000$. To go on paying its way, it is necessary for British manufactured products upon which, together with its invisible exports, depends its ability to pay for imports, to continue to be as good or better than those of its competitors, while at the same time prices must not be higher. To this end, increased mechanisation and increased use of knowledge are necessary and "it is essential that the floodgates of international trade should be opened and that some measure of stability and freedom should be given to currency systems". These topics are discussed whenever men meet, but not so often do we hear of the necessity of financing industrial research, without which we shall fail to sell many of our products. "If a country had to choose between new knowledge and gold ... the wise choice would undoubtedly be new knowledge for with it the gold can be obtained whereas without it the gold will be lost."

One hundred years ago there was no such thing as organised industrial research, and progress depended either on isolated research of men of genius or on accidental and unrelated observations. Later, in the nineteenth century, scientific men at the universities were occasionally asked to solve some of the problems of industry, but with the growth of the electrical, chemical and metallurgical industries, which depend on science for their very life, our industrial research laboratories came into being. "These laboratories aim at preventing industrial waste, at the standardisation of processes of manufacture and of the products, at lessening the costs of production and at the production of new types of goods. Their work does not replace the pure research work carried out at the Universities. It is supplementary to it. The outstanding characteristic of pure research is that it aims at increasing know. ledge irrespective of application and it cannot be organised in the same way as industrial research. As Sir Joseph J. Thomson has said, 'Great ideas in science are as wayward as the fancies of a poet, and they cannot be controlled and organised.'"

Though industrial research has made great headway in Great Britain and the greatest and most successful undertakings have research laboratories of their own, this country is in many respects still doing less than some of its competitors; "there is with many industries far too much timidity and hesitation, and these must be overcome if this country is to retain much of our old-time supremacy in manufacture and export more manufactured goods."

Referring to the scheme for co-operative industrial research associations initiated by the Department of Scientific and Induscrial Research in 1918, Sir Frank stated that there are now more than five thousand firms connected with the twenty research associations which have been set up. These firms have contributed about one and three-quarter millions to the cost of the work carried out. An investigation carried out by H.M. Chief Inspector of Factories covering nearly 128,000 factories employing about five million workers showed that less than five hundred of these factories employed more than one thousand workers each, while 117,147 factories employed less than one hundred workers each.i. It is well to urge that "industrial firms should build research laboratories, but it is obvious that not one of these 117,147 frms can take an effective part in industrial research as an isolated unit. ... Co-operative research is the only solution to the problem of applying science to small units."

Sir Frank Smith then proceeded to consider the relations between research and the national balance sheet, in the case of Great Britain's largest import, food-stuffs; its greatest material asset, buildings; and its greatest natural asset, coal. He pointed out that the scientific study of refrigerating devices, which not so long ago were, like the photoelectric cell, mere toys of the laboratory, together with the

No. 3291, VoL. 130] 
investigation of the biological problems involved in the transport and storage of foodstuffs, are doing much to help the national balance sheet by reducing imports through preventing waste.

In industrial processes care is taken to keep wear and tear of plant at a minimum and to design plant which is not likely to be obsolete, in such a way that replacement costs are comparatively small. The nation's most valuable plant is in the form of buildings, the value of which is estimated by Sir Frank at $£ 4,500,000,000$. Here science is helping by better planning and construction and by showing the builder how to choose his materials to greater advantage.

In the case of coal there are four ways in which research can help the trade balance: first by mechanising still further the hewing of coal and increasing the use of machinery in mines, thereby increasing our production power; secondly, by discovering means of obtaining more units of useful power from the fuel burnt; thirdly, by better marketing made possible by the application of the results of a scientific and comprehensive survey of our coal resources now being carried out; and fourthly, by the discovery of new and better methods for converting coal into powder, liquid and gaseous forms and the full utilisation of these forms.

\section{University and Educational Intelligence}

BristoL.-The annual Henry Herbert Wills memorial lecture will be delivered on December 15 at 5.15 P.M. in the Wills Laboratory by Lord Rutherford. The title of the lecture will be "Atomic Transformations". Admission will be by ticket obtainable from the Secretary.

LEEDS.-The honorary distinction of emeritus professor has been conferred upon Profs. F. W. Eurich, C. M. Gillespie, and R. S. Seton, who recently retired from the chairs of forensic medicine, philosophy and agriculture respectively.

LoNDON.-The following degrees have recently been awarded: D.Sc. degree in biochemistry to Prof. E. C. Dodds (professor of biochemistry at Middlesex Hospital Medical School) for published papers on hormones, supported by 42 other papers and 3 books; D.Sc. degree in botany to Helen Kemp Archbold (Imperial College-Royal College of Science and Bedford College) for a thesis entitled "Ripening Processes in the Apple and the Relation of the Time of Gathering to the Chemical Changes in Cold Storage" (Ann. Bot., July, 1932) ; D.Sc. degree in chemistry to Mr. J. R. I. Hepburn (East London College and Northern Polytechnic) for five published papers on "The Vapour Pressure of Water over Aqueous Solutions of Inorganic Electrolytes", and Ramsinha Thakur (Imperial College-Royal College of Science) for a thesis entitled "Three-Carbon Tautomerism in Dicyclic Systems"; D.Sc. degree in physics to Mr. J. H. Jones (King's College) for a thesis entitled "The Diffraction of Elastic Waves at the Boundaries of a Solid Layer Embedded in a Medium Possessing Lower Elastic Wave Velocities" (Proc. Roy. Soc., A., 1932) ; D.Sc. in chemistry to Mr. B. S. Evans for twelve independent published works in inorganic analytical chemistry, together with four conjoint subsidiary contributions.

A statement for the academic year 1931-32 has been issued by the Rhodes Trust, Seymour House, Waterloo Place, London, S.W.1, from which it appears that, during the year, 71 Rhodes scholars took up their scholarships at the University of Oxford for the first time. The total number of scholars in residence during the year was 196, comprising 103 from the British Empire, 89 from the United States and 4 from Germany. Classifying the scholars by the subjects read, there are 42 taking natural science and medicine, 7 mathematics and 2 forestry.

THE annual conference of the Geographical Association will be held at the London School of Economics, Houghton Street, Aldwych, W.C.2, on January 4-6, and at the Imperial Institute, South Kensington, on January 7. The presidential address will be delivered by Dr. H. R. Mill on "An Approach to Geography" on January 4. Among the lectures to be given at the Conference are : Mr. J. M. Scott : "The British Arctic Air Route Expedition, 1930-31", Mr. G. Huxley : "The Work of the Empire Marketing Board" ; the Right Hon. Lord Meston : "Contrasts in the Ganges Basin"; Prof. Kenneth Mason: "The Exploration of the Himalaya"; Prof. R. G. Stapledon : "Climate and the Improvement of Hill Grazings" ; and Sir John Russell : "Modern Changes in the Sources of our Food Supplies". Further information can be obtained from the Clerk, Geographical Association, Municipal High School of Commerce, Princess Street, Manchester.

\section{Calendar of Geographical Exploration}

\section{Nov, 28, 1605.-Discovery of Australia}

Willem Janszoon of Amsterdam sailed in the Duifken from Bantam, Java, hoping to discover more about New Guinea. He reached the coast of New Guinea in lat. $5^{\circ} \mathrm{S}$. and followed the shore round Prince Frederick Henry Island to the beginning of Torres Strait. Thence he steered south and traced the eastern shores of the Gulf of Carpentaria to $13^{\circ} 45^{\prime} \mathrm{S}$. Janszoon thought the coast was part of New Guinea. Attempts to open up trade with the sparse groups of natives failed, nine of the crew being murdered by them. The Spanish, under Torres, in the 1605-7 expedition discovered the true nature of Torres Strait, but not until 1762 was this realised, for Spain was then entering on a period of decadence and the results of the voyage were overlooked. Whatever vague reports of a southern land may have existed before the voyage of the Duifken, Janszoon's exploration of the Gulf of Carpentaria forms the first record of the discovery of Australia.

Dec. 3, 1738. - La Vérendrye and his Sons

Pierre Gaultier de Varennes, Sieur de la Vérendrye, reached a Mandan village, after having for the first time in this latitude crossed long. $100^{\circ} \mathrm{W}$. La Vérendrye began his famous career of exploration in Canada in 1726, constantly aiming at reaching the Pacific Ocean. In this he failed, but on his last journey (1738) he accomplished more than half the distance between Montreal and the Pacific. To him and to his sons is due the pioneer opening of the beginning of that route west of Winnipeg along which the Canadian Pacific Railway afterwards went. The La Vérendryes discovered Lake Manitoba, explored the Saskatchewan to the junction of the two main branches and established many forts. La Véren. drye's eldest son was killed in 1738 by Indians, but the other two in 1742 set out with Mandan guides and reached a mountain range with snow-clad peaks, probably the Rockies, though possibly the Bighorn Mountains.

No. 3291, VoL. 130] 